\title{
CURRENT TENDENCIES IN ESP DIDACTICS - INSIGHTS OF AN ESP JOURNAL EDITOR
}

\begin{abstract}
English for Specific Purposes (ESP) is a demanding field for its practitioners regarding its methodology, pedagogy, didactics, for numerous factors, primarily, it having a paradoxical position within the field of English language teaching due to at once its undeniable presence and relevance but rare academia institutional establishment, and still not having a consolidated relevant theoretical basis. Practice of teaching ESP involves dealing with real life issues of how to teach a group of students who need this instruction for clearly pre-determined reasons, and therefore, what approach to use, which material, grammatical units, and alike. Stemming from actual teaching experiences, there appear valuable insights, opinions, research results of ESP practitioners as formulated and presented in the form of journal articles, which even more than in other fields become primary sources of familiarizing with current and emergent approaches in ESP didactics. As an Editor-in-Chief of an ESP scientific journal, the author presents discernible, most prominent tendencies in ESP methodology, pedagogy, didactics worldwide over, which summarize current theoretical and practical basis of this form of language teaching and intercultural communication.
\end{abstract}

KEYWORDS: English for Specific Purposes; research; practitioner; methodology; topics.

1 nadezda.stojkovic@elfak.ni.ac.rs

This paper was submitted on August $10^{\text {th }}, 2019$ and accepted for publication at the meeting of the Editorial Board held on September $16^{\text {th }}, 2019$. 
Teaching of English as a Foreign Language (EFL) in high schools initiates students into basic language terminology used in scientific/ professional field for which they are beginning to prepare. In academia then, language instruction focuses on detailed preparation for the specific domain, and that is English for Specific Purposes (ESP) (Mackay \& Mountford, 1978). This implies elaborate, very particular, very demanding work of the ESP lecturers throughout the course, before commencement, during, and in its reviewing phase. The specificities of the practitioners' work concern the lack of official training in ESP methodology, and consequently their own coping with all the crucial aspects of their job. To name the major ones, those would be material design according to the linguistic profile of the curriculum of the Higher Education (HE) institution and the jobs range it leads to.

To achieve that, lecturers are to familiarize with a professional and scientific field they have not been trained for or may even have no inclinations for. The most adequate strategy in doing so is collaborating with professors of the major subjects, inquiring about as much as possible. There may arise difficulties, or rather incompleteness in this sort of exchange, and whether they do or not, the practitioner certainly will need to educate themselves into that science, its branches, and content. Moreover, this is not required only before they begin their job, but constantly throughout their careers, as today sciences evolve rapidly. In order to match linguistic profile of that setting, they need to come up with texts and exercises, working on which will help develop in students the awareness of the needed lexis, grammatical and syntactical structures, and make them skillful enough in those to perform successfully in the designated scientific and professional area. Practitioners are to compose the syllabus of the respective ESP course with clear statements of its aims and goals, competencies that will be achieved upon its finalization, teaching methodology that would best ensure those (Dudley-Evans \& St John, 1998; Belcher, 2004).

At the initial phases of ESP theory, largely still valid, its main proponents, Hutchinson and Waters described the practitioners as "dwellers in a strange and uncharted land" (Hutchinson \& Waters, 1987: 158). The primary reason for this is that still, decades upon the inception of ESP as an approach to ELT, and its undeniable 
direct relation to the effectiveness in contemporary international science and economy to the advantage over teaching only General English (GE) in academia, English philology departments far too rarely offer courses of ESP instruction for students who go into teaching profession. To our knowledge, in Europe there is Mykolas Romeris University, Vilnius, Lithuania, which offers a Bachelor degree program in English for Specific Purposes ${ }^{2,3}$, and University of Durham, UK, with a master's degree program. ${ }^{4}$ Occasionally, some universities in the UK offer ESP courses, yet not as graduate programs, and those mostly on demand. Thus, in the literature on the theoretical basis of ESP, its practitioners are described as simultaneously acting in all five key roles (Dudley-Evans \& St John, 1998), those being a teacher, course designer and material provider, collaborator, researcher, and evaluator.

At the time when English is indisputably the bridge language, and speaking of the adult population - that is English for scientific and professional purposes mostly, therefore ESP, it comes as a paradox that the lecturers who impart precisely that approach to language are still, persistently, left to their own regarding almost all aspects of their work. Then, it comes as no surprise that dedicated journals become platforms for sharing insights, research findings, and case studies. Browsing through those, one can find a wealth of valuable ideas, well presented and defended, that can fit their teaching setting and improve it. Also, there are simmered directions of areas that need to be investigated more. In the case of ESP, it is thus journal articles that contain theory, discussions, exchange of ideas, opinions, practice, that are invaluable support for the practitioners (Hedgcock, 2002).

\section{REPRESENTATIVE TOPICS AND RESEARCH PRESENTATION FEATURES}

As for The Journal of Teaching English for Specific and Academic Purposes ${ }^{5}$, of which the author is the Editor-in-Chief, the prevailing

2 Mykolas Romeris University, Vilnius, Lithuania, is to begin their ESP MA program the following academic school year.

3 https://stdb.mruni.eu/siulomu_programu_sarasas.php?l=en

4 https://www.dur.ac.uk/englishlanguage.centre/postgraduate/matesol/esp/

5 Official web-page: http://espeap.junis.ni.ac.rs/index.php/espeap 
topics concern segmentation within the scope of ESP, such being English for IT, medicine, tourism, aviation, engineering, pharmacy, fine arts, agriculture, mathematics, border guards, but also to rarer fields like rehabilitation, special education, midwifery, cynology. Those being particular ESP/EAP areas of practice and research, the theses most frequently center upon pillars - syllabus and material design, methodology, goals of instruction, discourse and corpus analysis, translation, textbooks writing, enhancing students' motivation, cultural and policy issues within a HE institution or a country, CLIL, EMI, still to name merely a few 6 .

For example, when material design is investigated, authors stress textbook material need be content-based, subject specific, relevant for students' core studies. There is one of the main sources of motivation for in/after classroom activities. Yet, as a collection of set materials, it is only a core matrix as information is readily available from various sources nowadays, which calls for preparing students for independent and lifelong learning. And in accordance with contemporary ESP methodological recommendations, this approach allows for a student-centered environment in which learners acquire knowledge in English, rather than about English, concurrently improving their English, just in a different manner from students to whom it is a major study language.

Another of crucial topics is integration of translation into the teaching context of ESP. Here translation is argued to assist in finding more appropriate ways of integrating both specific content and teaching as a way to achieve more relevant results in particular domain language teaching. At the same time, ESP teaching includes specific knowledge, language skills (vocabulary, grammatical structures, and alike). The overarching rationale for implementing translation into the ESP is that it supports interdisciplinary character of ESP teaching and optimizes the teaching process.

(Inter)cultural competencies are often explored as vital to ESP with the main argument that companies and academia today are more and more ethnically and racially diverse. In such settings, colleagues express themselves through their varied perspectives, values, and behaviours. Failure to understand and respond to social and cultural differences hinders communication, and hence needs to be incorporated into an ESP syllabus.

6 The intention of the author is to present representative topics, not advertise the journal itself. Therefore, the article is of an overview, summary type, without referencing each topic presented. 
There are papers that present investigations on the causality between language teaching and the social context, putting forward the contemporary notion that literacy extends beyond the reading and writing to include among other skills, intercultural awareness and critical thinking. At HE settings, literacy is expected to ensure a perpetually harmonious link between skills acquisition and the realities of the labor market. This societal need is the core of ESP courses whose aim is to analyze the discourse of the domain profession/science and convey it successfully to the students, thus enhancing their possibilities for better employment, the rationale of ESP at HE.

Closely related is the internationalization of HE institutions, and the labor markets respectively, with English as a major tool of communication. There arose a new strand in distinguishing among various uses of this language, one such being English as a medium of instruction (EMI). It is closely inspected in terms of who teaches EMI and is contrasted with ESP, raising numerous debatable issues pertaining to who is prepared to take over the task of linguists, as well as to what extent can linguists be trusted to convey content matter. Then, distinction is made towards content language integrated learning (CLIL) and its distinctive characteristics from both EMI and ESP.

Academic writing occupies great attention of authors interested in either atomistic approach dealing with introduction and practice of discrete elements, or those in favor of a holistic understanding that aims at developing students' awareness of how academic writing pieces are developed by critically examining and evaluating a chosen text. It is always stated that academic writing is not practiced only for those intending to pursue academic career, but that it is an inherent part of writing practices often met (in particular formats) in business sectors as well.

Problem based learning is a method often recommended in ESP settings, and much discussed among authors. Based on the premise that it prepares students for crucial $21^{\text {st }}$ century skills as it integrates problem solving skills development, and students' learning about how to think through facilitated problem solving and self-directed learning. Recommendations for the effective integration of problem-based learning in ESP programs, course curriculum and teaching materials, are provided.

Use of technologies is another much researched topic. One of the directions in such investigations is the potential of such teaching 
and learning aids to help foster students' learning autonomy, by exploring the ways and goals in their usages. It is suggested that E-media bring the process of foreign language acquisition even closer to native language acquisition by creating real time tasks and contexts for meaningful learning, and that students acquire and memorize new meanings of English more efficiently when they autonomously use technology to construct knowledge. Educational technological applications are presented and classified according to their communicative and cognitive potential, much in line with the Semantic Theory, Constructivist Theory of Learning, Cognitive Linguistics, and Communication Theory.

Specific contemporary social issues calling for pressing attention are also addressed. One of such is faster and efficient integration of refugees into society, with the prime argument that the command of both the language of the host country and ESP will allow those people increased self-confidence stemming from better educational perspectives and ultimately broader employment opportunities. It is argued that this type of instruction will help remove the barriers between them and the rest of the host society, provide for the necessary dialogue, accelerate adaptation, and fasten the process of their integration in multicultural environments.

\section{EDITOR'S REMARKS}

There are some strikingly evident tendencies among approximately a hundred papers received yearly. One is heavy reliance on statistical tools, the other absence of personal teaching experience and insights, in author's opinion both found to be interdependent, and not commendable. The first is largely present in contemporary linguistics. The move towards devising and applying methodology of research that can measure performance and provide verified data in favor or declining a particular thesis relevant for better teaching outcomes is certainly justifiable. This has well been proven valid and has therefore become rationale for its use. Research based on posing a research question, then careful collection of data through various forms of questionnaires distributed to students or lecturers, its categorization, and then statistical analysis of the obtained results with which the initial thesis is answered whichever way, confirmed or negated, significantly improves the teaching of ESP by establishing it on solid grounds. What is, however, obvi- 
ous is, to the opinion of the author, the overuse of statistics in ESP/ EAP related articles. The general impression is that lecturers are trained in applying such tools, that they know the structure of research based on those, and then undergo to collect data on issues that any slightly experienced lecturer would know at a glance in a classroom, without any surveys, correlations, or analysis of variance. Then one asks oneself why do these colleagues endeavor that? Do they not see the futility of such research, why do they not apply critical thinking over it? (The skill they are supposed to teach their students). Or could it be that it has appeared as some sort of linguistic research fashion and for that reason it is indiscriminately used? At the same time, it seems that authors shy from expressing their own, personal professional experience, built on years of work, mastery of their profession. Reasons for this could be various, though possibly primarily related to the previously noted tendency that is gaining dominance, and the authors may be of the opinion that voicing solely their own experience can be perceived as outdated and overcome. Moreover, long absence of finding such papers probably leaves one thinking which academic writing format would be appropriate. The author finds this be a profound lack and misjudgment on the part of the authors. The intricate, heavily demanding idiosyncrasies of teaching an ESP course simply call for exchange of valuable solutions resulting from reports on personal viewpoints, solutions, and opinions.

Another area that is far too rarely investigated relates to the pedagogy of teaching. Whereas psychology is dealt with most notably through motivational issues as crucial for the successful finalization of the course, pedagogy seems to have lost its relevance. The author is of the opinion that the causes for this can be found in the essential premises of ESP courses, but also HE institution policies. ESP is founded on performativity principles, much in line with Lyotard's (1984) understanding of that concept, focusing solely on high effectiveness in the professional area.

Finally, there are almost no papers that are critical towards ESP/ EAP, much in line with what Sarah Benesch terms lack of engagement on the part of the practitioners who remain "essentially pragmatic" (Benesch, 2008: ix). While a plethora of papers, of research, is profoundly concerned with critical approaches to ESP discourse, and despite the rise of critical social theory, fundamental questions about ESP practice, the overwhelming and domineering role of standardized formats of publications, of needs analysis principles- 
that fundamental defining criterion of ESP-remain unquestioned for their societal and possible ideological underpinnings.

$\begin{array}{ll}\text { SOURCES } & \text { Mykolas Romeris University, Vilnius, Lithuania, Bachelor degree program } \\ \text { on English for Specific Purposes, https://stdb.mruni.eu/siulomu_progra- } \\ \text { mu_sarasas.php?l=en, } \\ \text { The Journal of Teaching English for Specific and Academic Purposes, http:// } \\ \text { espeap.junis.ni.ac.rs/index.php/espeap } \\ \text { University of Durham, UK, master's degree program, https://www.dur.ac.uk } \\ \text { /englishlanguage.centre/postgraduate/matesol/esp/ }\end{array}$

REFERENCES Belcher, D. (2004). Trends in Teaching English for Specific Purposes. New York: Palgrave Macmillan.

Benesch, S. (2008). Critical English for Academic Purposes: Theory, Politics, and Practice. Lawrence Erlbaum Associates, Inc., Publishers.

Dudley-Evans, T. \& St John, M. (1998). Developments in ESP: A multi-disciplinary approach. Cambridge: Cambridge University Press.

Hedgcock, J. S. (2002). Facilitating Access to Communities of Practice in Language Teaching: Toward a Socioliterate Approach to Teacher Education. The Modern Language Journal, 86 (3), 299-317.

Hutchinson, T. \& Waters, A. (1987). English for specific purposes: A learning-centred approach. Cambridge: Cambridge University Press.

Lyotard, J. F. (1984). The Postmodern Condition: A Report on Knowledge. Manchester: Manchester University Press.

Mackay, R. \& Mountford, A. (Eds.). (1978). English for Specific Purposes. London: Longman.

НАДЕЖДА М. СТОЈКОВИЋ

УНИВЕРЗИТЕТ У НИШУ

ЕЛЕКТРОНСКИ ФАКУЛТЕТ

КАТЕДРА ЗА ОПШТЕОБРАЗОВНЕ ПРЕДМЕТЕ

РЕзИмЕ АКТУЕЛНИ ТРЕНДОВИ У ДИДАКТИЦИ ЕНГЛЕСКОГ ЗА ПОСЕБНЕ НАМЕНЕ:
УВИДИ УРЕДНИКА ЧАСОПИСА

Енглески за посебне намене је захтевно поље за предаваче у смислу методологије, педагогије и дидактике из више разлога. Међу најзначајнијима су његова парадоксална позиција у оквиру области наставе енглеског језика у коју га доводи неспорно 
присуство и значај, али и недовољно учвршћена позиција у академском окружењу, као и одсуство консолидоване релевантне теоријске основе. Настава енглеског за посебне намене подразумева решавање реалних проблема у раду са студентима којима је он потребан из јасно дефинисаних разлога, као и питања одаठира наставног приступа, материјала, граматичких јединица и слично. Реално искуство из наставе обезбеђује неопходне увиде, ставове, резултате истраживања наставника енглеског за посебне намене формулисане и представљене у облику научних радова објављених у академским часописима, који чак више него у другим пољима постају примарни извор информација о актуелним и новим приступима у дидактици енглеског за посеঠне намене. Као главни и одговорни уредник научног часописа посвећеног овом пољу, аутор овде представља запажене, најуочљивије тенденције у свету када су у питању методологија, педагогија и дидактика енглеског за посебне намене, а које представљају актуелну теоријску и практичну основу ове врсте наставе енглеског језика и интеркултуралне комуникације.

КључнЕ РЕчи: енглески за посебне намене; истраживање; пракса; методологија; теме.

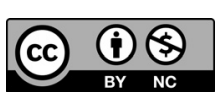

Овај чланак је објављен и дистрибуира се под лиценцом Creative Commons Ауторство-Некомерцијално Међународна 4.0 (CC BY-NC 4.0 |

https://creativecommons.org/licenses/by-nc/4.0/).

This paper is published and distributed under the terms and conditions of the Creative Commons Attribution-NonCommercial International 4.0 licence (CC BY-NC 4.0 | https://creativecommons.org/licenses/by-nc/4.0/). 